Corrigendum

\title{
Corrigendum to "Gene Expression Profiles of Human Phosphotyrosine Phosphatases Consequent to Th1 Polarisation and Effector Function"
}

\author{
Patricia Castro-Sánchez, Rocio Ramirez-Munoz, and Pedro Roda-Navarro \\ Department of Microbiology I (Immunology), School of Medicine, \\ Complutense University and "12 de Octubre" Health Research Institute, Madrid, Spain
}

Correspondence should be addressed to Pedro Roda-Navarro; proda@med.ucm.es

Received 19 October 2017; Accepted 26 October 2017; Published 10 December 2017

Copyright (C) 2017 Patricia Castro-Sánchez et al. This is an open access article distributed under the Creative Commons Attribution License, which permits unrestricted use, distribution, and reproduction in any medium, provided the original work is properly cited.

In the article titled "Gene Expression Profiles of Human Phosphotyrosine Phosphatases Consequent to Th1 Polarisation and Effector Function" [1], there was an error in Figure 2 where the calibration bar should indicate 20 in the red side and 5 in the blue side. The correct figure is as follows. 


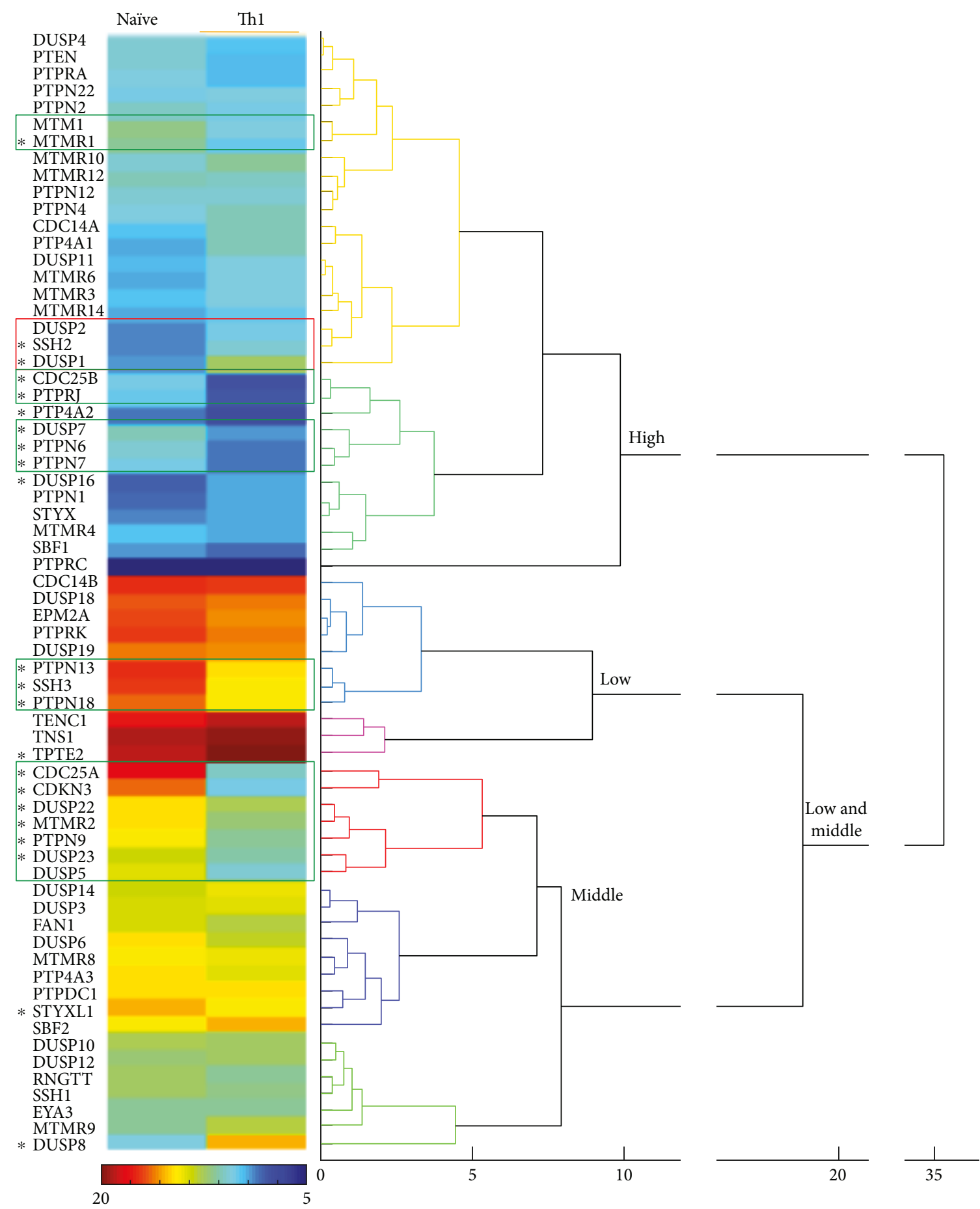

Figure 2: Agglomerative hierarchical tree of the gene expression patterns in naïve and Th1 cells. Numbers below the tree indicate the distance among gene patterns. Heat map represents the average DCT obtained for each gene in both conditions and 3 donors. The calibration bar is shown between 5 and 20 DCTs. Green and red squares point to clusters of upregulated and downregulated genes, respectively. Asterisks indicate those genes whose expression levels were considered to significantly change, as detailed in Table 2, and explained in Materials and Methods. Clusters are indicated of high, middle, and low expression. 


\section{References}

[1] P. Castro-Sánchez, R. Ramirez-Munoz, and P. Roda-Navarro, "Gene expression profiles of human phosphotyrosine phosphatases consequent to Th1 polarisation and effector function," Journal of Immunology Research, vol. 2017, Article ID 8701042, 12 pages, 2017. 


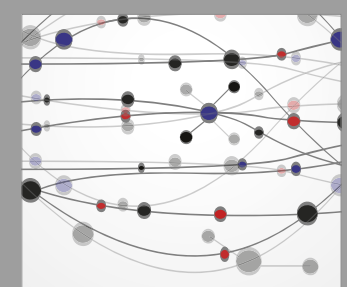

The Scientific World Journal
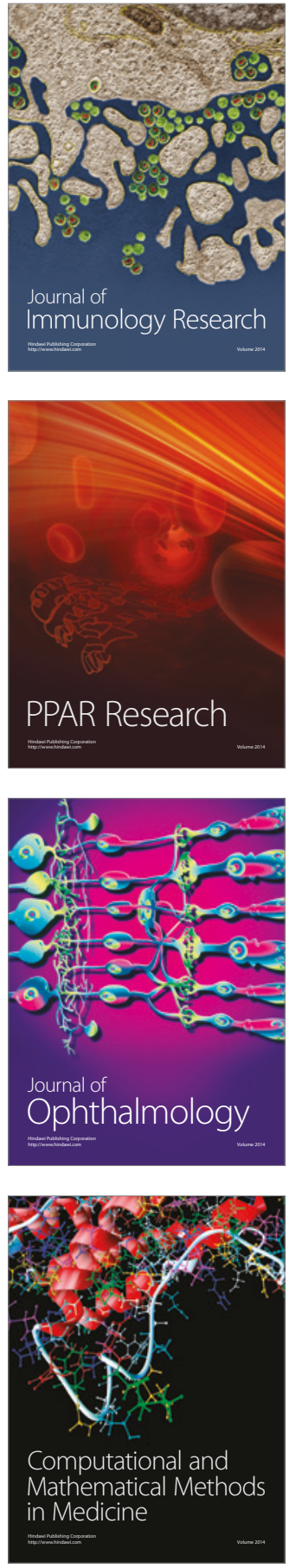

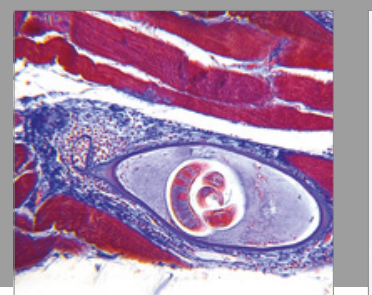

Gastroenterology Research and Practice
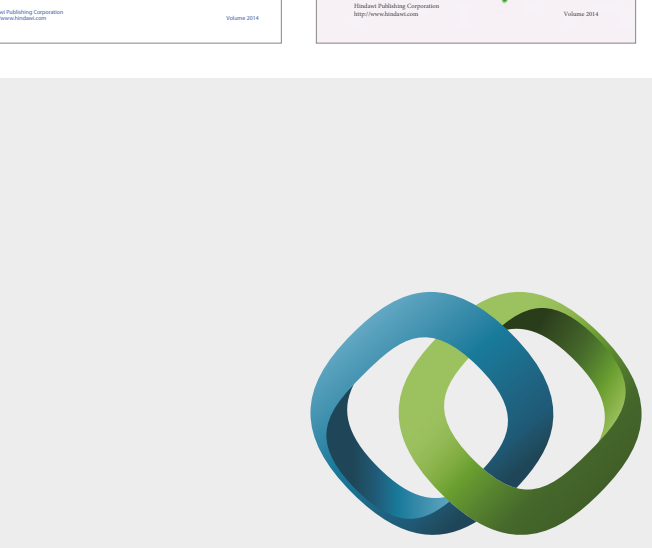

\section{Hindawi}

Submit your manuscripts at

https://www.hindawi.com
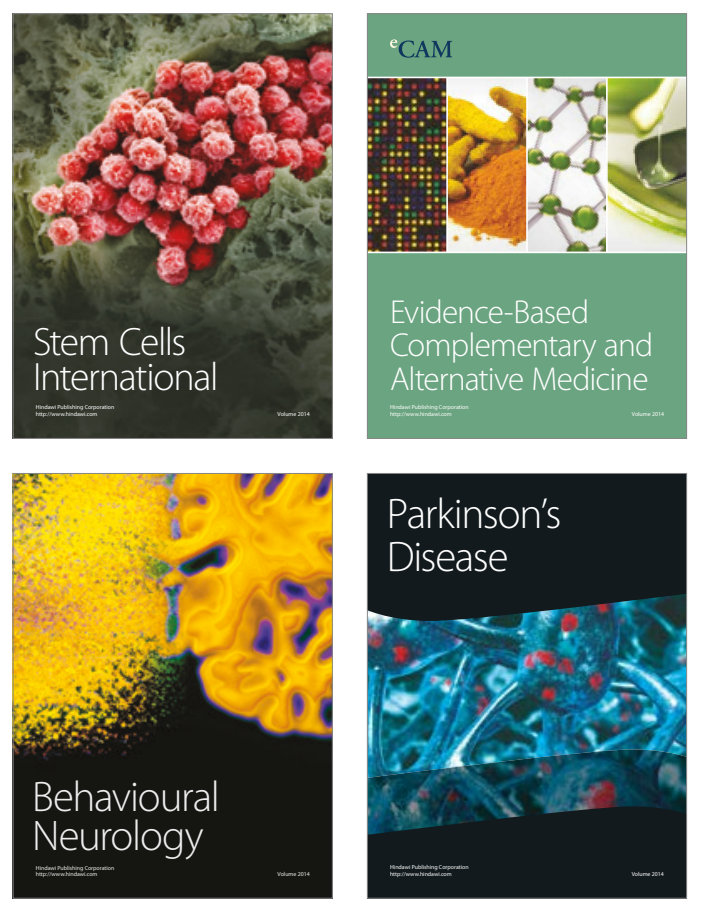
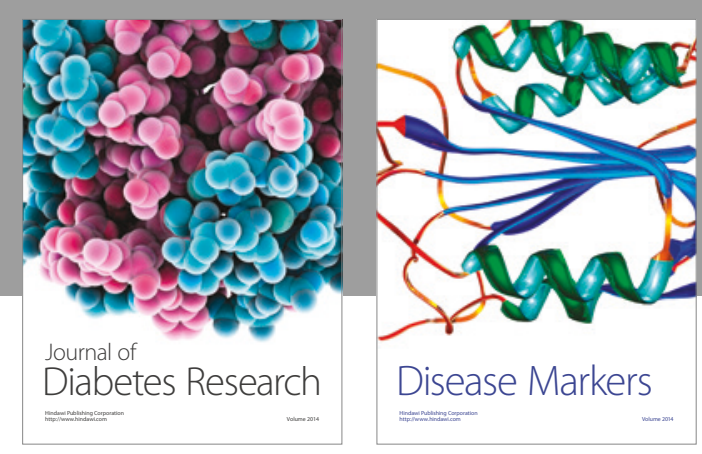

Disease Markers
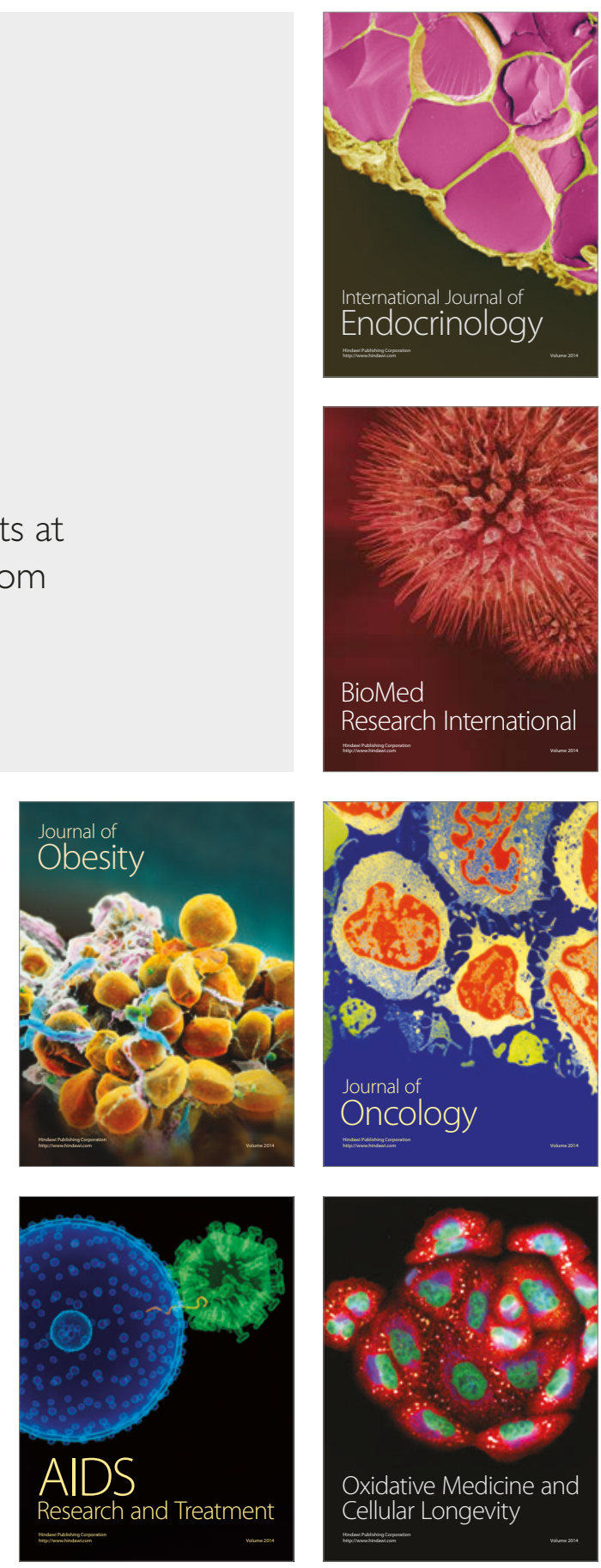